Institute of $\mathbf{F}_{\text {ood and }} \mathbf{A}_{\text {gricultural }} \mathbf{S}_{\text {ciences }}$

\title{
Birdfeeders: What to Consider When Selecting ${ }^{1}$
}

\author{
Mark E. Hostetler, Martin B. Main, and Maena Voigt ${ }^{2}$
}

The history of birdfeeding in America dates back to 1845 , when Henry David Thoreau fed birds at Walden Pond. In 1926, the first commercially made birdfeeder, designed for hummingbirds, went on the market. Today, more than 50 million Americans put out a billion pounds of birdfeed each year.

Before placing a feeder in your backyard, you should think about a few key points. The following suggestions are useful guidelines. The BEST way to determine how to attract birds to your feeders is to experiment. For example, try different feeders located at different spots in your yard and place the feeders at different heights.

\section{Location of Feeder}

What makes a good location for a feeder? A good location is:

- where you have a good view of the feeder from where you intend to watch the birds.

- one with easy access, especially important on days with bad weather and for cleaning up messes.
- at least 10 to 15 feet away from tree limbs or trunks so squirrels can't jump onto the feeder.

- approximately 15 feet from bushes. This distance should give birds the opportunity to fly into bushes to escape from aerial predators, such as hawks. This distance should also protect birds from cat predation; a cat cannot hide close to the feeder.

- either away from windows or use window decals to discourage birds from flying into windows.

- away from high traffic areas, such as where kids play or a pet area.

Also, if you have the space, consider placing several feeding stations throughout your yard. This is effective for two reasons. First, some birds like to feed near vegetation and others out in the open. By placing feeders in different localities, you will have a greater diversity of birds using your feeders. Second, this will help spread out the birds and help control overtly aggressive individuals that chase other birds away from a particular feeder.

1. This document is WEC 162, one of a series of the Department of Wildlife Ecology and Conservation, Florida Cooperative Extension Service, Institute of Food and Agricultural Sciences, University of Florida. First published September 2003. Please visit the EDIS Web site at http://edis.ifas.ufl.edu for more UF/IFAS publications.

2. Mark E. Hostetler, Wildlife Extension Specialist and Assistant Professor, Dept. of Wildlife Ecology and Conservation; Martin B. Main, Associate Professor, Dept. of Wildlife Ecology and Conservation, Southwest Florida Research and Education Center, Immokalee; Maena Voigt, graduate student, Dept. of Wildlife Ecology and Conservation, Institute of Food and Agricultural Sciences, Florida Cooperative Extension Service, University of Florida, Gainesville, FL 32611.

The use of trade names in this publication is solely for the purpose of providing specific information. UF/IFAS does not guarantee or warranty the products named, and references to them in this publication do not signify our approval to the exclusion of other products of suitable composition. Use of company names in this publication does not signify our approval to the exclusion of other companies that offer comparable products and services.

The Institute of Food and Agricultural Sciences is an equal opportunity/affirmative action employer authorized to provide research, educational information and other services only to individuals and institutions that function without regard to race, color, sex, age, handicap, or national origin. For information on obtaining other extension publications, contact your county Cooperative Extension Service office. Florida Cooperative Extension Service/Institute of Food and Agricultural Sciences/University of Florida/Christine Taylor Waddill, Dean. 


\section{Types of Feeders}

Choose a feeder based upon what species and the number of birds you would like to attract (Table 1). Platform feeders have been cited in studies as having a higher rate of disease transmission among birds due to the increased chance of birds standing in fecal droppings. To reduce this risk, use platform feeders that are constructed with wire mesh on the bottom. This allows droppings to be washed away during a rain and the seeds will dry much faster. Wet seed tends to spoil rapidly.

Feeders can be selective or non-selective for a particular species. Platform feeders tend to be non-selective since many species of birds can use them. Tube feeders (Figure 1), because of the small perches, will be used by small, perching birds like goldfinches. Suet feeders, which contain rendered fat or peanut butter, attract woodpeckers as well as bluebirds. Thistle feeders are specifically used for thistle seeds and tend to attract primarily finches. Nectar feeders are also unique in providing nectar substitutes. Fruit feeders will attract orioles during the spring and fall migration. Hopper feeders attract a wide variety of species depending on the size of the perching ledge and the height of the feeder. Hopper feeders (as well as platform feeders) that are placed low to the ground tend to attract more ground-foraging species such as sparrows and doves.

\section{Food}

The type of food you stock your feeder with plays a role in which birds you will attract. Providing improper or spoiled food to birds is dangerous to their health. When attracting hummingbirds, use sugar, not honey, due to a fungal disease spread by honey. Remember that suet and hummingbird nectar can spoil in the hot sun. Don't use birdseed coated with a red or pink dye. The dye is capstan, a fungicide that can kill wild birds.

Bags of mixed seed usually contain more unwanted food, such as milo, than wanted food, such as sunflower seed. Birds will empty your feeder trying to get to their favorite food. Most birds seem to prefer black oil sunflower. Buy the hulled variety so that the leftover seed cases won't attract rodents. If you'd like to attract orioles, thrashers, and bluebirds,

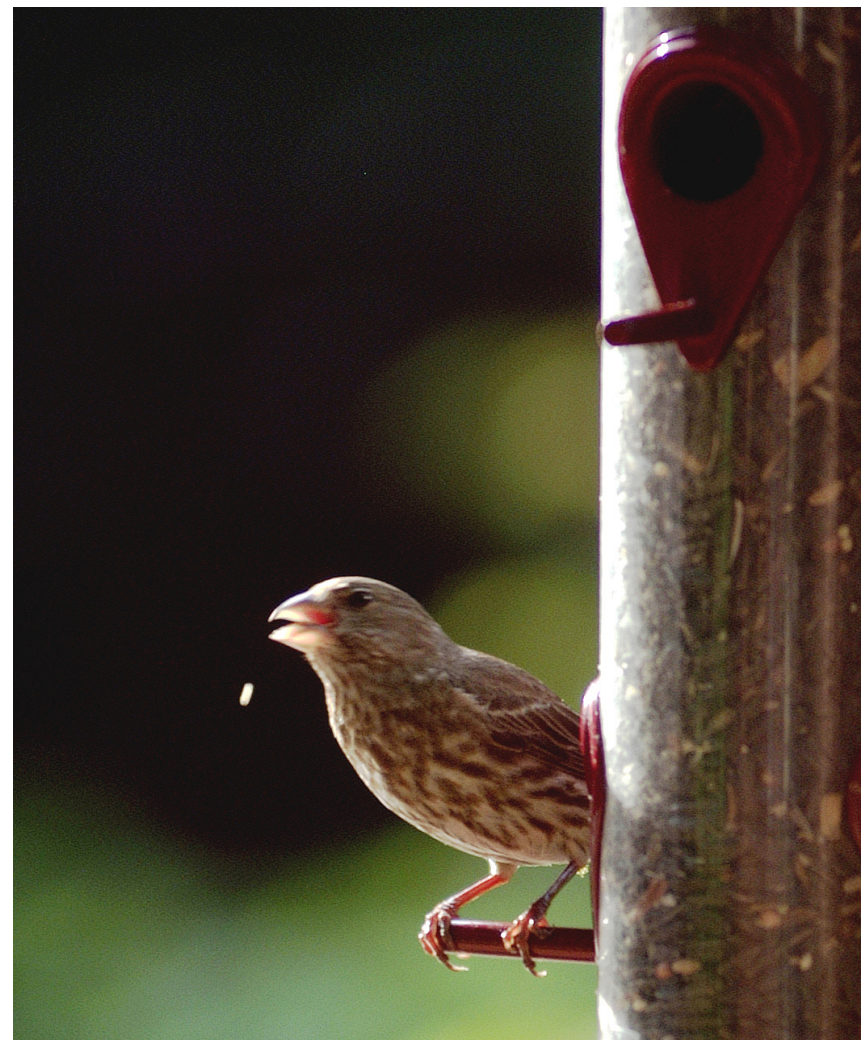

Figure 1. House finch at a tube feeder. Bags of mixed seed usually contain more unwanted food, such as milo, than wanted food, such as sunflower seed. Birds will empty your feeder trying to get to their favorite food -- black oil sunflower seeds for most birds. Photo by Tom Wright, UF/IFAS Communication Services.

put out fruit. Nuthatches, woodpeckers, and wrens eat suet. You can buy specific foods commercially or make it at home. Here are some recipes for:

- Hummingbird Nectar - make by adding 1/4 cup sugar to 1 cup boiling water (making it any sweeter could be lethal to the birds). Do not use honey. Cool the solution before putting into the feeder.

- Suet - heat suet/beef fat over low heat until melted, let cool. Heat it again until melted (heating twice will make it better for hanging in warmish weather). Turn off heat. Allow the suit to cool until slightly thickened, then add 2 cups corn flour and 1 cup dried fruit, seeds, or nuts, depending on what type of birds you want to attract. Let it cool and shape into a ball.

- Pine Cone - smother pine cone in peanut butter and then roll it in birdseed. Hang the pine cone from a tree limb by a string or wire. This is a good activity to do with children. 


\section{Cleaning}

It is essential to maintain a clean birdfeeding environment in order to discourage disease. Remove moldy seed from feeders and clean up seed spilled on the ground. Clean birdfeeders regularly. Depending on the amount of use a feeder receives, it is a good idea to clean and let a feeder dry out at least once a month. Check a feeder frequently for wet or spoiled seed, especially after a heavy rain. Heat and humidity are perfect conditions for mold growth.

Hummingbird feeders should be cleaned at least once a week or bi-weekly, depending on how hot it is outside. Clean hummingbird feeders with hot water and vinegar. Try to place the hummingbird feeder in a shady location. Keep an eye on the hummingbird feeder and the consistency of the sugar-water. If the water appears cloudy, take the feeder down immediately. Clean it and fill it with new sugar-water solution. Thistle, sunflower and suet feeders should be cleaned at least once a month.

To clean glass, ceramic and plastic birdfeeders (except hummingbird feeders), use a $10 \%$ bleach solution (1 part bleach to 10 parts water) and hot water. Clean hummingbird feeders with hot water and vinegar. To clean wooden birdfeeders, use hot soapy water and a bristle brush. Each season, change the location of your feeder to insure a clean ground for the birds.

\section{Squirrels}

Squirrels like to visit birdfeeders, too, and can quickly consume all the birdseed. To discourage squirrels, try a feeder on a pole with a baffle or purchase a squirrel-proof feeder. When selecting a hanging feeder, buy one with metal mesh or a dome. If you store your birdseed supply outside, it is best to keep it in a securely closed metal container. Squirrels can chew through heavy plastic containers.

\section{Cats}

Cats kill millions of birds each year. To keep your feeder safe from cats:

- place birdfeeders away from areas where cats can lay in wait to attack birds.
- keep your cat indoors. Putting a bell on your cat will not stop it from attacking birds. At the very minimum, do not allow cats to be outside from sunrise to about 3 hours after sunrise. Many birds feed most heavily in the morning.

- do not leave unwanted cats in rural areas.

- don't feed stray cats; eliminate their food sources, such as garbage, on your property.

\section{Additional Information}

1. Acme Wild Bird Feeder Company, a division of BestNest. Online :

http://www.acmewildbirdfeeders.com

2. Cats Indoors! Campaign. American Bird Conservancy. Online: http://www.abcbirds.org/cats/catsindoors.htm

3. Dennis, J.V. 1999. Bird Feeding: The Beginnings. Birders' World vol 13, pg 50. Online: http://web4.infotrac.galegroup.com

4. Kaytee: Bird Feeding -- Finding the Right Food. Online:

http://www.kaytee.com/wild/feeding/

finding.html

5. National Bird-Feeding Society. The Dynamics of Bird Feeding. Online: http://www.birdfeeding.org

6. Schaefer, J. and C.N. Huegel. February 2001. University of Florida, IFAS. Florida's Hummingbirds. Online: http://edis.ifas.ufl.edu/BODY_UW059

7. U.S. Fish and Wildlife Service, Office of Migratory Bird Management. Backyard Bird Feeding. Online: http://migratorybirds.fws.gov/pamphlet/feed.html 
Table 1. Common backyard birds and the types of birdfeeders they prefer.

\begin{tabular}{|c|c|c|c|c|c|c|c|c|}
\hline Bird & $\begin{array}{l}\text { Tube } \\
\text { Feeder }\end{array}$ & $\begin{array}{c}\text { Platform } \\
\text { Feeder }\end{array}$ & $\begin{array}{c}\text { Hopper } \\
\text { feeder }\end{array}$ & $\begin{array}{l}\text { Thistle } \\
\text { Tube } \\
\text { Feeder * }\end{array}$ & $\begin{array}{l}\text { Hanging } \\
\text { Suet } \\
\text { Feeder ** }\end{array}$ & $\begin{array}{c}\text { Peanut } \\
\text { Butter } \\
\text { Suet } \\
\text { Feeder }\end{array}$ & $\begin{array}{c}\text { Fruit } \\
\text { Feeder }\end{array}$ & $\begin{array}{l}\text { Nectar } \\
\text { Feeder }\end{array}$ \\
\hline American Goldfinch & $x$ & & & $x$ & & $x$ & & \\
\hline Eastern Bluebird & & & & & & $x$ & $x$ & \\
\hline House Finch & $x$ & $x$ & $x$ & $x$ & & & $x$ & \\
\hline Hummingbird & & & & & & & & $\mathrm{x}$ \\
\hline Jays & & $x$ & $x$ & & & $x$ & & \\
\hline Northern Cardinal & & $x$ & $x$ & & $x$ & $x$ & & $x$ \\
\hline Nuthatches & $x$ & & & & $x$ & $x$ & & \\
\hline Orioles & & & & & & & $x$ & $x$ \\
\hline Song Sparrow & & $x$ & & & & & & \\
\hline Titmice & $\bar{x}$ & $\bar{x}$ & $x$ & & $x$ & & & \\
\hline Warblers & & & & & $x$ & & & \\
\hline Woodpeckers & & & & & $x$ & $x$ & $x$ & $x$ \\
\hline Wrens & & & & & $x$ & & & \\
\hline
\end{tabular}

